\title{
The Importance of Preschool Teacher-Child Attachment for Healthy Childhood Development
}

\author{
Petra Dolenc \\ University of Primorska \\ petra.dolenc@pef.upr.si
}

\begin{abstract}
The last decades have seen a growing interest in researching preschool teacher-child relationships, particularly how the quality of attachment to a teacher impacts children's overall development. In this context, preschool teachers represent an important figure who, away from home environment, provide care, physical security, and emotional support. This article offers an overview of relevant studies dealing with various aspects of attachment at an early age, highlighting the importance of preschool teacher-child attachment quality for children's developmental outcomes. Secondly, the article offers some suggestions for promoting secure relationships in early childhood education, especially during settling a child into the kindergarten environment.
\end{abstract}

Keywords: attachment theory, preschool teacher-child relationships, early childhood education

\section{Attachment and Attachment Theory}

Attachment theory developed by John Bowlby (2005) is one of the betterknown theories of contemporary developmental psychology. It assumes that infants need a consistent nurturing relationship with one or more sensitive caregivers in order to develop into healthy individuals. Positive ad close relationships in early years are predictive of later social competence and mental health and resilience in children (World Health Organization 2004; Winston and Chicot 2016) Inappropriate relationships are considered to contribute to aberrant behavior and in combination with other risk factors to psychopathology (Rosmalen, Van der Veer and Horst 2015).

Attachment can be defined as a strong and reciprocally positive relationship between two people (Marjanovič Umek and Zupančič 2009). An affectionate bond between a child and his or her caregiver (usually a parent), is established based on innate signals that an infant uses to seek proximity of another person at times of distress. On the other hand, the caregiver has also got an inherent capacity to respond to child's specific signals, providing both 
protection and comfort (Bowlby 1991; Cugmas 2003). The key element within the attachment theory is the concept of the secure base that refers to the provision of a reliable and safe base by caregiver from which the infant can venture out and explore into the environment and to which the child can return in case of perceived threat (Bowlby 2005).

Attachment develops gradually; this process includes several stages that depend on children's experiences in the interaction with their caregiver and on their overall development and maturation (Marjanovič Umek and Zupančič 2009). Drewery and Bird (2004 in Du Plessis 2009) argue that attachment relationships are particularly relevant in the earliest years of life when infants are not yet able to care for themselves and, therefore, need a reliable caregiver to provide care. Attachment can be understood as a complex bidirectional relationship influenced by individual characteristics of both members of the dyad. According to Sierra (2012) these include characteristics of parents (e. g., their health status, psychological state, possible problems with addiction, stress or background of insecure attachment), children's characteristics (e. g. health problems, premature birth, temperament) and characteristics of the context (e. g. extreme deprivation, violent environment).

Bowlby's attachment theory underlines the importance of child's attachment to the mother which, according to experts, represents the primary object of attachment, in the sense of her sensibility to offer support and comfort to an infant (Cugmas 2009). The history of mother-child interactions is the foundation for shaping an attachment pattern which further influences various aspects of development (Cortazar and Herreros 2010).

\section{Quality of Attachment}

Mary Ainsworth provided empirical support for Bowlby's theory by using the Strange Situation procedure as an analytical tool to assess attachment style and the quality of early attachments. This procedure assumes short separations and reunions between the child and the parent. Different attachment patterns are a result of repetitive experiences of caregiving and can be divided in two basic categories: secure and insecure (Mooney 2010).

The quality of attachment is established according to the following principles: attachment behaviors and relationships between two people are continuously growing; mother-child interactions influence the psychological capacities of both; the emotional bond between a mother and a child is shaped by a specific social context (Sierra 2012).

In the optimal situation, infants experience care by mothers which are mostly reliable, sensitive and attuned to their needs and temperament char- 
acteristics. The synchrony between the child's needs and mother's responses is a good predictor of secure attachment (Ainsworth 1978 in Mooney 2010). Secure relationships enable infants to express distress and accept consolation easily and encourage the exploration of the environment with the certainty that their caregiver will be available if needed (Furnivall et al. 2012). Avoidant attachment is a form of insecure attachment, which is not characterized by a child's protest or distress at separation from the reference person, nor pleasure on reunion (Ainsworth 1978 in Mooney 2010). Avoidantly attached infants learn to inhibit negative emotions (such as anger and sadness) because they realize that the caregiver is unable to tolerate their distress and react either aggressively or by withdrawal (Furnivall et al. 2012). Infants with anxious-resistant attachment style tend to respond with anger and resistant behavior towards the parent, exhibiting extreme distress at the time of separation and difficulties in calming on the reunion (Ainsworth 1978 in Mooney 2010). They are preoccupied whether the caregiver will reliably respond to their needs. Caregivers of those infants were found to be inconsistent in responses and insufficiently sensitive to signals of the child. Disorganized attachment was subsequently added to the Ainsworth classification system as fourth attachment style, characteristic of children who respond in situations of separation and reunion with their caregiver in a confusing, contradictory and unpredictable way (e.g., after the return of the reference person they begin to cry when it already seemed that they have been comforted (Marjanovič Umek and Zupančič 2009). Some authors claim that these conflicting behaviors are the consequence of the infant being exposed to extremely frightened or frightening reactions by a caregiver. This leaves the child unable to develop a consistent strategy that would bring to a sense of security (Furnivall et al. 2012).

Even though the primary purpose of the attachment is to ensure proximity of the primary caregiver in order to receive protection and reduce stress in case of perceived danger, the attachment behaviors affect various aspects of cognitive, social and emotional development (Cortazar and Herreros 2010; Stefanović-Stanojević, Tosić-Radev and Velikić 2015). Commodari (2013a) summarizes a number of studies according to which attachment security in the earliest years of life influences cognitive performance in childhood, promote prosocial behaviors, self-esteem, and life satisfaction in adolescence, as well as social adjustment and psychological well-being in early adulthood. More recent research in the field of neurodevelopment (Newman, Sivaratnam, and Komiti 2015) emphasizes the importance of safe and supportive emotional environment for healthy brain functioning. 


\section{Preschool Teacher-Child Attachment}

Many studies have shown that infants and toddlers, irrespectively of their attachment to parents, can develop attachment to other non-parental figures. The transition from home to preschool is a particularly critical period characterized by numerous changes in children's early life, such as separation from parents, being in a new setting, unknown people and unfamiliar routines (Datler et al. 2012). Young children begin to spend more and more time with early childhood caregivers or preschool teachers, so they can be seen as attachment-relevant and represent some kind of 'secondary' attachment figures (Cugmas 2009; Pedditzi and Rollo 2014; Sierra 2012; Verschueren and Koomen 2012).

Over the past decade there has been an increased research interest in the study of children's attachment to preschool teacher (Cugmas 2011; Du Plessis 2009; Pedditzi and Rollo 2014; Veríssimo et al. 2017; Verschueren and Koomen 2012), who play a key role in providing care, safety and education in out-of-home environment. Children's attachment to teachers co-exists with the attachment to their parents and bears similar attachment patterns. Howes and Ritchie (1999) describe four types of attachment to teachers: secure, avoidant, resistant and near-secure. The avoidant type is characteristic of children who are more interested in the materials in the playroom rather than in the teacher or peers. When experiencing frustration, they do not seek the teacher, or even move away if the teacher tries to console them. In a resistant pattern of attachment, children are irritable with the teacher, even without reason, and often demanding and impatient. Children with secure attachment seek comfort and spontaneously hug the teacher when feeling distressed or angry; they like to share activities with the teachers and others and ask for help if needed. In a near-secure attachment, children show a combination of moderately avoidant and secure behaviors. They tend to distrust the teacher, but they participate in all activities. Therefore, the teacher often fails to recognize a problem in such a relationship.

Veríssimo et al. (2017) have found that building a close, attachment-relevant relationship with a teacher in early childhood is, only in part, a function of the quality of parent-child attachment relationships. Furthermore, some authors suggest the idea that attachment styles can be discontinued by life circumstances or new relationship (Cortazar and Herreros 2010). In this regard, secure preschool teacher-child attachment may compensate for a more problematic parent-child relationship. Buyse, Verschueren, and Doumen (2011) have found that especially for children who are less securely attached to 
their mothers, sensitivity of the preschool teacher may be the crucial factor in the development of close teacher-child relationship and reduction the risk of aggressive behavior among children.

As noted by Pianta the key qualities of teacher-child relationship appears to be related to the ability of an adult at accurately reading the child's signals, to respond contingently on the basis of these signals, to convey acceptance and emotional warmth, to offer assistance as necessary, and to model regulated behavior (Pianta 1999, 67, in Du Plessis 2009). Similarly, Cugmas (2009) explains that the teacher's sensitivity to children's needs most strongly determines the pattern of their attachment behavior.

Preschool teacher-child attachment depends on several factors, including attributes of teachers, attributes of children, as well as environmental factors. Recent research findings have provided evidence that higher education level of teachers, lower perceived stress and higher self-efficacy are related with higher quality relationships with young children (Chen and Phillips 2018; Choi and Dobbs-Oates 2016). There is a growing body of research demonstrating that preschool teacher-child relationships are also predicted by children's temperamental characteristics (Acar et al. 2018). Especially reactivity as a sub-dimension of temperament was found to have a significant impact on teacher-child relationships (Yoleri 2016).

Within early childhood education, teachers play a critical role in providing emotional and social security, promoting children's language and cognitive development, encouraging children in the process of socialization with adults and peers outside their family. They also play an extremely important role during settling into childcare helping children navigate through this new experience. Therefore, it is among teachers' priorities to build a good affective bond based on sensitive responsiveness to children's needs. The fact that preschool teacher represents a secure base is very important especially with younger and more vulnerable children who come from an emotionally less supportive environment (Buyse et al. 2011; Verschueren and Koomen 2012).

\section{Preschool Teacher Attachment and Children's Development}

Recent research results suggest that quality of a preschool teacher-child relationships predict children's emotional, social and cognitive development during the early childhood period as well as through elementary years and even later in life (Commodari 2013b; Mashburn et al. 2008; Mortensen and Barnett 2015).

Sroufe (2005) stressed the importance of infant attachment, both because of its place in initiating pathways of development and because of its con- 
nection with so many critical developmental functions - social relatedness, arousal modulation, emotional regulation, and curiosity. Children with histories of secure attachment (assessed at 12 and 18 months) faced less social problems in preschool years, displayed more curiosity and flexibility in handling problems than children with histories of insecure attachment. Moreover, preschool children with early secure attachment were much more empathic and popular among peers, exhibited less aggressive behavior than the children with histories of insecure attachment. Failure to develop secure attachments in early life may lead to later difficulties in communicating and managing emotions with peers (Sroufe 2005). Cugmas (2010) summarizes the research findings according to which the quality of preschool education and of teacher's relationships is closely associated with children's well-being and integration in preschool classrooms. When children feel well and relaxed at kindergarten, they are more satisfied and confident, they express their needs and desires, they are open to new experiences and adapt easily. It was discovered that there is a positive connection between a secure preschool teacherchild attachment and children's success in social interaction, speech development, and symbolic play. Children with a secure attachment style are more co-operative and more likely to accept tasks given by their teachers. Moreover, children who experience a secure attachment showed more perseverance and they were more successful in solving mental tasks (Commodari 2013a). Mortensen and Barnett (2015) assume that the teacher-child relationships that develop in infant/toddler child care provide a critical caregiving context for young children's socioemotional development.

A review of relevant research has revealed that there is a positive connection between secure attachment to teacher and children's cognitive development. A study conducted by Howes and Smith (1995 in Commodari 2013a) including infants, toddlers, and pre-schoolers, examined children's play activities and cognitive activities as well as their relationships with caregivers within the child care setting. It has been established that preschool teacher's social interactions (e. i., encouragements, smiles, physical proximity) and children's feeling of security and attachment to the teacher were related to enhanced cognitive activities and more exploration during play activities in all three developmental stages.

Early observational studies (Main 1983 in Commodari 2013b) showed that three-year-olds with secure attachment experiences manifested larger attention spans during play compared to those with insecure attachment patterns. Some researchers have discovered that securely attached preschool children tend to have improved attention abilities and better scholastic 
skills before entering school compared to insecurely attached preschoolers (Bergin and Bergin 2009). More specifically, Commodari (2013b) demonstrated that children with secure preschool teacher attachment presented better attention skills, in terms of higher reaction time and better selectivity and maintenance. Mashburn et al. (2008) who examined the development of academic, language and social skills among four-year-olds in preschool programs found that positive and close preschool teacher-child interactions may facilitate their school readiness. A recent study, exploring children's representations of attachment and positive teacher-child relationships, revealed that a close attachment-relevant relationship with preschool teachers in early childhood may be related to higher children's verbal capacity (Veríssimo et al. 2017).

According to several authors (Buyse et al. 2011; Cortazar and Herreros 2010; Mortensen and Barnett 2015; Sierra 2012) early childhood education has an extremely important role in child development, especially when it comes to children from a deprived environment or at risk due to adverse caregiving experiences. The author states that preschool teachers represent significant attachment figures, which can create a safe and friendly environment that promotes development and learning, as well as contributes to social acceptance of the child. Many studies have also shown that children's attachment to their mothers as their primary caregivers should not be always compared to a teacher-child attachment. However, children can build a secure attachment to other non-parental figures despite having experienced an insecure parental attachment in the past (Pedditzi and Rollo 2014; Sierra 2012). Thus, encouraging a secure preschool teacher-child attachment may compensate an eventually anxious parental attachment (Cugmas 2010). High-quality early childhood education and positive attachment to preschool teacher have proven to be an important factor of compensation with children coming from less supportive home environments in the sense of insufficient sensitivity and responsiveness for the child's needs.

\section{Conclusions and Proposals for Applying Attachment Theory in Early Childhood Education}

There is a growing body of literature trying to integrate attachment theory into early childhood settings (Cortezar and Herreros 2010; Niecki 2017; Shirvanian and Michael 2017). In order to bridge attachment theory and early childcare practice, Shirvanian and Michael (2017) highlight the importance of training and professional development within attachment theory for preschool teachers. Research shows that interventions within attachment 
theory for preschool teachers, such as education and training programs enhance children's secure attachment and sensitivity in the caregivers (Shirvanian and Michael 2017). Pedditzi and Rollo (2014) suggest that additional teacher training should be introduced to early childhood education which would allow preschool teachers to learn about attachment theory in order to identify actual characteristics of a secure attachment and consequently respond appropriately to children's needs.

A child's transition to childcare or kindergarten represents the first experience away from home with an alternate caregiver. Thus, attachment theory allows for an adequate explanation of a child separation anxiety. Taking into account the principles of the theory, teachers can alleviate children's distress also by letting parents be present in the group for a few days during the settling-in period. A child can be also encouraged to bring a favorite toy or other objects which have the role of a transitory object that replaces home environment and parents, and make a child feel safe and more easily comforted during parental absence.

Some children experience the transition to kindergarten even before attachment is fully developed, therefore, consistency in caregiving is essential for the child's attachment (Goldberg, Muir, and Kerr 2013). For this reason, the practice of keeping a group of children with the same teacher for more than a year has the potential to provide a consistent caregiver during the young child's critical period of attachment and emotional development (Nitecki 2017). Cugmas (2010) assumes that preschool teachers can help relieve children's distress due to separation from their parents with using symbolic play or through storytelling. Preschool teachers who become familiar with attachment theory have better insight into the structure and dynamics of relationships between children and caregivers and therefore, better understand children's behavior. Teachers can also evaluate how children's behaviors relate to the quality of parental attachment by observing the reactions of children and their parents after morning separation and after reunion when parents come to pick their children up from kindergarten.

Early childhood educators can play an important compensatory role for the most vulnerable children with insecure attachment patterns with primary caregivers. They can foster secure secondary attachment offering a predictable environment, consistent and sensitive care, appropriate frequent physical contacts, and a space where needs, emotions, and temperament characteristics of children are recognized (Cortezar and Herreros 2010; Shirvanian and Michael 2017).

Higher education can also play an important role by including more spe- 
cialized courses on implementing attachment theory within the context of infant/toddler child care in preschool teachers preparation programs. Practical training for future preschool teachers should promote sensitivity to differences in attachment styles in order to facilitate secure relationships and healthy socioemotional outcomes for young children.

\section{References}

Acar, I. H., J. C. Torquati, A. Encinger, and A. Colgrove. 2018. 'The Role of Child Temperament on Low-Income Preschool Children's Relationships with Their Parents and Teachers.' Infant and Child Development 27 (1): e2045. http://www.researchgate.net/publication/318169236_The_role_of_child _temperament_on_low-income_preschool_children\%27s_relationships _with_their_parents_and_teachers

Ainsworth, M. S. 1978. Patterns of Attachment: A Psychological Study of the Strange Situation. Hillsdale, NJ: Erlbaum.

Bergin, C., and D. Bergin. 2009. 'Attachment in the Classroom.' Educational Psychology Review 21:141-170.

Bowlby, J. 1991. Separation: Anxiety and Anger. Vol. 2 of Attachment and Loss. New York: Penguin.

- 2005. A Secure Base: Clinical Applications of Attachment Theory. London: Routledge.

Buyse, E., K. Verschueren and S. Doumen. 2011. 'Preschoolers' Attachment to Mother and Risk for Adjustment Problems in Kindergarten: Can Teachers Make a Difference?' Social Development 20:33-50.

Chen, S., and B. Phillips. 2018. 'Exploring Teacher Factors that Influence TeacherChild Relationships in Head Start: A Grounded Theory.' The Qualitative Report 23 (1): 80-97.

Choi, J. Y., and J. Dobbs-Oates. 2016. 'Teacher-Child Relationships: Contribution of Teacher and Child Characteristics.' Journal of Research in Childhood Education 30 (1): 15-28.

Commodari, E. 2013a. 'Preschool Teacher Attachment, School Readiness and Risk of Learning Difficulties.' Early Childhood Research Quarterly 28 (1): 123133.

_ 2013b. 'Preschool Teacher Attachment and Attention Skills.' SpringerPlus 2:673. https://www.ncbi.nlm.nih.gov/pmc/articles/PMC3872284/

Cortazar, A., and F. Herreros. 2010. 'Early Attachment Relationships and the Early Childhood Curriculum.' Contemporary Issues in Early Childhood 11 (2): 192-202.

Cugmas, Z. 2003. 'Odraz socialnega vedenja otrok z različnim vzorcem navezanosti na vzgojiteljico v otroški risbi.' Psihološka obzorja 12 (2): 49-63.

- 2009. 'Kakovost vrtca in otrokova navezanost na vzgojiteljico.' Sodobna pedagogika 60 (3): 40-50. 
. 2010. 'Uporaba teorije navezanosti v vrtcih.' Pedagoška obzorja 25 (1): 3-18.

- 2011. 'Relation between Children's Attachment to Kindergarten Teachers, Personality Characteristics and Play Activities.' Early Child Development and Care 181 (9): 1271-1289.

Datler, W., K. Ereky-Stevens, N. Hover-Reisner, and L. E. Malmberg. 2012. 'Toddlers' Transition to Out-of-Home Day Care: Settling into a New Care Environment.' Infant Behavior \& Development 35 (3): 439-451.

Drewery, W., and L. Bird. 2004. Human Development in Aotearoa: A Journey through Life. Auckland: McGraw Hill.

Du Plessis, K. 2009. 'Early Childhood Teacher-Child Attachment: A Brief Review of the Literature.' He Kupu 2 (1). http://www.hekupu.ac.nz/article/early -childhood-teacher-child-attachment-brief-review-literature

Furnivall, J., M. McKenna, S. McFarlane, and E. Grant. 2012. Attachment Matters for All - An Attachment Mapping Exercise for Children's Services in Scotland. N. p.: CELCIS.

Goldberg, S., R. Muir, and J. Kerr. 2013. Attachment Theory: Social, Developmental, and Clinical Perspectives. London: Routledge.

Howes, C., and S. Ritchie. 1999. 'Attachment Organizations in Children with Difficult Life Circumstances.' Development and Psychopathology 11 (2): 251268.

Howes, C., and E. Smith. 1995. 'Relations among Child Care Quality, Teacher Behavior, Children's Play Activities, Emotional Security, and Cognitive Activity in Child Care.' Early Childhood Research Quarterly 10:381-404.

Main, M. 1983. 'Exploration, Play, and Cognitive Functioning Related to Infant-Mother Attachment.' Infant Behavior and Development 6: 167-174.

Marjanovič Umek, L., and M. Zupančič. 2009. Razvojna psihologija. Ljubljana: Znanstvenoraziskovalni inštitut Filozofske fakultete.

Mashburn, A. J., R. C. Pianta, B. K. Hamre, J. T. Downer, O. A. Barbarin, D. Bryant, M. Burchinal, D. M. Early, and C. Howes. 2008. 'Measures of Classroom Quality in Prekindergarten and Children's Development of Academic, Language, and Social Skills.' Child Development 79:732-749.

Mortensen, J. A., and M. A. Barnett. 2015. 'Teacher-Child Interactions in Infant/Toddler Child Care and Socioemotional Development.' Early Education and Development 26 (2): 209-229.

Mooney, C. G. 2010. Theories of Attachment: An introduction to Bowlby, Ainsworth, Gerber, Brazelton, Kennell, and Klaus. St. Paul, MN: Redleaf Press.

Newman, L., C. Sivaratnam, and A. Komiti. 2015. 'Attachment and Early Brain Development: Neuroprotective Interventions in Infant-Caregiver Therapy.' Translational Developmental Psychiatry 3 (1). http://www.tandfonline.com/ doi/full/10.3402/tdp.v3.28647

Nitecki, E. 2017. 'Looping and Attachment in Early Childhood Education: How 
Applications of Epigenetics Demand a Change.' Journal of the Scholarship of Teaching and Learning 17 (2): 85-100.

Pedditzi, M. L., and D. Rollo, D. 2014. 'L' attacamento nell'asilo nido: Le educatrici hanno una visione monotropica o poliadica?' Psicologia clinica dello sviluppo 18 (1): 143-152.

Pianta, R. C. 1999. Enhancing Relationships between Children and Teachers. Washington, DC: American Psychological Association.

Rosmalen, L., R. Van der Veer, and F. Horst. 2015. 'Ainsworth's Strange Situation Procedure: The Origin of an Instrument.' Journal of the History of the Behavioral Sciences 51 (3): 261-284.

Sierra, P. G. 2012. 'Attachment and Preschool Teacher: An Opportunity to Develop a Secure Base.' International Journal of Early Childhood Special Education 4 (1): 1-16.

Shirvanian, N., and T. Michael. 2017. 'Implementation of Attachment Theory into Early Childhood Settings.' The International Education Journal: Comparative Perspectives 16 (2): 97-115.

Sroufe, L. A. 2005. 'Attachment and Development: A Prospective, Longitudinal Study from Birth to Adulthood.' Attachment \& Human Development 7 (4): 349-367.

Stefanović-Stanojević, T., M. Tosić-Radev, and D. Velikić. 2015. 'Maternal Attachment and Children's Emotional and Cognitive Competences.' Psychological Topics 24 (1): 51-69.

Veríssimo, M., N. Torres, F. Silva, C. Fernandes, B. E. Vaughn, and A. J. Santos. 2017. 'Children's Representations of Attachment and Positive Teacher-Child Relationships.' Frontiers in Psychology 8:2270. http://www.ncbi.nlm.nih.gov/ pmc/articles/PMC5743748/

Verschueren, K., and H. M. Y. Koomen. 2012. 'Teacher-Child Relationship from an Attachment Perspective.' Attachment \& Human Development 14 (3): 329336.

Winston, R., and R. Chicot. 2016. 'The Importance of Early Bonding on the LongTerm Mental Health and Resilience of Children.' London Journal of Primary Care 8 (1): 12-14.

World Health Organization. 2004. The Importance of Caregiver-Child Interactions for the Survival and Healthy Development of Young Children: A Review. Geneva: World Health Organization.

Yoleri, S. 2016. 'Teacher-Child Relationships in Preschool Period: The Roles of Child Temperament and Language Skills.' International Electronic Journal of Elementary Education 9 (1): 210-224.

\section{Pomen navezanosti na vzgojiteljico za zdrav razvoj otroka}

V zadnjih desetletjih je opaziti povečan raziskovalni interes na področju preučevanja odnosa med otrokom in vzgojiteljco v vrtcu, zlasti v smislu pomena ka- 
kovosti otrokove navezanosti na vzgojiteljico za njegov celostni razvoj. Vzgojiteljica v tem kontekstu pomeni tisto pomembno osebo, ki otroku izven domačega okolja zagotavlja nego, fizično varnost in čustveno oporo. V prispevku predstavljamo pregled relevantnih raziskav, ki obravnavajo različne vidike in dejavnike otrokove navezanosti na vzgojiteljico, pri čemer poudarjajo pomen kakovostne navezanosti na vzgojiteljico za otrokov razvoj na različnih področjih, ter izpostavimo načine, s katerimi lahko spodbujamo varno navezanost med otrokom in vzgojiteljco v vrtcu, zlasti v obdobju otrokovega uvajanja v vrtčevsko okolje.

Ključne besede: teorija navezanosti, odnos med vzgojiteljico in otrokom, predšolska vzgoja 